\title{
Covid-19: Migrant Workers in Singapore and Humanitarian View
}

\author{
Irda Nalls* \\ MA in Applied Linguistics, Ph.D in Education and Human Development, University of Colorado, USA
}

*Corresponding author: Irda Nalls, MA in Applied Linguistics, Ph.D in Education and Human Development, University of Colorado, USA.

Received Date: May 11, 2020

Published Date: June 01, 2020

\begin{abstract}
Covid-19 has been given the status of a global pandemic, and while it is merely a virus that attacks one's immune system, this virus also managed to remind us about humanity. This article raised an awareness on the lack of humanity among an educated society as the author considered the plight of migrant workers in Singapore. Adopting critical whiteness lens in a reflective narrative approach, the author emphasized on the need for a different kind of education as Singaporeans progress as an educated nation. Utilizing public data and current affairs reported daily during the time of Covid-19 in Singapore, the author described the living conditions of migrant workers in Singapore, and their deteriorating health as they battle Covid-19 while working to build homes for Singaporeans, the very people who take a stand that did not support their mental and physical well-being.

Keywords: Covod-19, migrant workers, Singapore, global pandemic
\end{abstract}

\section{Opinion}

Singapore is one of the richest country in Asia with a GDP of S\$88, 991 per capita Singstat [1]. Despite being a meritocratic country, economically driven society, a great amount of investment is also put into her gaining recognition as a beautiful garden city, densely populated with an estimate of 5, 850, 342 Singaporeans permanent residents (PR) Worldometers [2]. 97.05\% of the locals are educated, marked as having received at least 10 -years of compulsory bilingual education Lee [3]. In addition to being a garden city, Singapore is also known for her high rise buildings (flats and offices) to hold her dense population. While well paid local Singaporeans, and foreign workers widely referred as expatriates, stand in the frontline of projects to ensure these high rise buildings are efficiently built to deliver the government's promise of a place to live, work, and play for all Singaporeans, let us not forget that it was, is, and will continue to be the underpaid migrant workers, mostly from third world countries like India and Bangladesh who will continue to put in their sweat and tears into actually laying the bricks one at a time, rain or shine, sickness and in health so that Singaporeans and PRs can continue to enjoy the fruit of their laborious work of art, Singapore's beautiful high-rise buildings, including the iconic Marina Bay Sands.

Covid-19 which has taken the world by storm, taking the lives of 20 reported cases in Singapore and this number is increasing by the minute reveals the uglies of an educated society. I am ashamed to be a part of this society, and this piece that I am writing applies critical whiteness Nalls [4] as I reflect on my own privileges as an educated born and bred Singaporean woman while discussing the status of migrant workers in Singapore who laboured and toiled to build our homes in good times, but they are "abandoned" in times of Covid-19 as they continue to exist on the periphery of the Singaporean society.

Recent reports in Singapore reported migrant workers being housed in make shift quarters on-site the construction projects that they are working on. These make shift quarters provide a shared sleeping mattress where up to 6 migrant workers will sleep on at scheduled time. They also have a small shared kitchen area to allow them to boil water, and a shared bathroom. Being miles away from their home country, they are also deprived of recreational facilities 
to occupy their pockets of free time. With minimal wage, their spending power to "live, work, and play" is also made unavailable to them. After all, they are only migrant workers; therefore, the same promise from the government to the persons living in Singapore should not apply to them as they are expected to live on the periphery of the Singaporean society.

Covid-19 situation brings the living condition of migrant workers in Singapore to the limelight because of the increasing daily numbers of migrant workers infected by the virus. Currently, that statistic stands at 20,939. This alarming statistics constitute a high percentage of migrant workers, which makes up more than $95 \%$ of the statistics, and majority of these workers are commanded to remain in their make-shift quarters and some kind of temporary holding because the hospitals do not have enough beds and medical facilities to care for them. Thus far, three migrant workers have died with Covid-19 and the rhetoric adopted by the Singaporean government is to provide separate statistics segregating migrant workers from local community spread. Such rhetoric used only continues to highlight that migrant workers are not a part of Singapore, and that they live on the "outskirts" of the society. There are also a number of Singaporeans who have raised the "solution" to send the migrant workers back to their home countries because the increasing number of infected migrant workers are keeping Singaporeans indoor during the Circuit Breaker (CB). While Singaporeans are cooped up in their homes, built by the foreign workers, in the comfort of their air conditioned rooms with a wide array of home deliveries and free streaming of movie channels and musicals on YouTube, foreign workers are carrying on with their routine of living in their shared make shift quarters or fighting for their lives away from loved ones in a hospital ward, battling Covid-19, and face a possible risk of deportation.

\section{Conclusion}

As a born, bred Singapore woman who is peeling off the layers of privileges that I am enjoying in the comfort of my study room, I reflect on the lives of the migrant workers in Singapore. They were born into poverty, leaving their third world countries, away from loved ones, to give their loved ones an opportunity to survive back home in India or Bangladesh. In trying times such as Covid-19, a recognized state of world pandemic, being humane becomes a necessity to survive this apocalyptic state. A first world country like Singapore who has been hailed as practicing model coping strategies in surviving Covid-19 need to be kind to one another, to grow a heart alongside a healthy GDP becomes important if we were to be the role model for the rest of the world. It is not a time to be divided, placing less than desired social net worth on the periphery. Instead, it is a time to stand together to build a better world with a growing humane heart as we value all lives, regardless of status.

\section{References}

1. Singstat (2020) Statistics Singapore.

2. (2020) Worldometers.

3. Lee K. Y (2011) My lifelong challenge: Singapore’s bilingual journey. Straits Times Press, Singapore.

4. Nalls I (2019) BFLA Spanish-English Mexican American bilinguals. Critical Inquiry in Language Studies 16(1): 30-49. 